\title{
Nephronectin as a Matrix Effector in Cancer
}

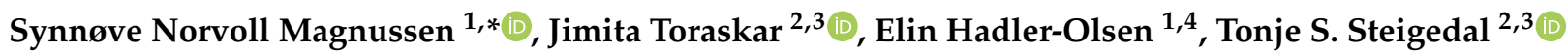 \\ and Gunbjørg Svineng ${ }^{1}(\mathbb{D}$
}

1 Department of Medical Biology, Faculty of Health Sciences, UiT-The Arctic University of Norway, 9037 Tromsø, Norway; elin.hadlerolsen@tffk.no (E.H.-O.); gunbjorg.svineng@uit.no (G.S.)

2 Department of Clinical and Molecular Medicine, Faculty of Medicine and Health Sciences, Norwegian University of Science and Technology (NTNU), 7491 Trondheim, Norway; toraskarjimita@gmail.com (J.T.); tonje.s.steigedal@ntnu.no (T.S.S.)

3 Cancer Clinic, St. Olavs Hospital HF, 7006 Trondheim, Norway

4 The Public Dental Health Service Competence Center of Northern Norway, 9271 Tromsø, Norway

* Correspondence: synnove.magnussen@uit.no

Citation: Magnussen, S.N.; Toraskar, J.; Hadler-Olsen, E.; Steigedal, T.S.; Svineng, G. Nephronectin as a Matrix Effector in Cancer. Cancers 2021, 13, 959. https://doi.org/10.3390/ cancers13050959

Academic Editors: Nikos Karamanos and Zoi Piperigkou

Received: 31 January 2021

Accepted: 22 February 2021

Published: 25 February 2021

Publisher's Note: MDPI stays neutral with regard to jurisdictional claims in published maps and institutional affiliations.

Copyright: (C) 2021 by the authors. Licensee MDPI, Basel, Switzerland. This article is an open access article distributed under the terms and conditions of the Creative Commons Attribution (CC BY) license (https:// creativecommons.org/licenses/by/ $4.0 /)$.
Simple Summary: The extracellular matrix provides an important scaffold for cells and tissues of multicellular organisms. The scaffold not only provides a secure anchorage point, but also functions as a reservoir for signalling molecules, sequestered and released when necessary. A dysregulated extracellular matrix may therefore modulate cellular behaviour, as seen during cancer progression. The extracellular matrix protein nephronectin was discovered two decades ago and found to regulate important embryonic developmental processes. Loss of either nephronectin or its receptor, integrin $\alpha 8 \beta 1$, leads to underdeveloped kidneys. Recent findings show that nephronectin is also dysregulated in breast cancer and plays a role in promoting metastasis. To enable therapeutic intervention, it is important to fully understand the role of nephronectin and its receptors in cancer progression. In this review, we summarise the literature on nephronectin, analyse the structure and domain-related functions of nephronectin and link these functions to potential roles in cancer progression.

Abstract: The extracellular matrix protein nephronectin plays an important regulatory role during embryonic development, controlling renal organogenesis through integrin $\alpha 8 \beta 1$ association. Nephronectin has three main domains: five N-terminal epidermal growth factor-like domains, a linker region harbouring two integrin-binding motifs (RGD and LFEIFEIER), and a C-terminal MAM domain. In this review, we look into the domain-related functions of nephronectin, and tissue distribution and expression. During the last two decades it has become evident that nephronectin also plays a role during cancer progression and in particular metastasis. Nephronectin is overexpressed in both human and mouse breast cancer compared to normal breast tissue where the protein is absent. Cancer cells expressing elevated levels of nephronectin acquire increased ability to colonise distant organs. In particular, the enhancer-motif (LFEIFEIER) which is specific to the integrin $\alpha 8 \beta 1$ association induces viability via p38 MAPK and plays a role in colonization. Integrins have long been desired as therapeutic targets, where low efficiency and receptor redundancy have been major issues. Based on the summarised publications, the enhancer-motif of nephronectin could present a novel therapeutic target.

Keywords: nephronectin; cancer; breast cancer; extracellular matrix; metastasis; cancer progression

\section{The Extracellular Matrix as a Regulator of Tissue Homeostasis}

The extracellular matrix (ECM) is a complex and dynamic non-cellular component of tissues performing many critical functions. The ECM maintains tissue integrity by providing a scaffold while also absorbing mechanical tension. Through ECM anchoring, cells are provided with cues that either maintain tissue homeostasis or induce cellular changes, such as those seen during development and wound healing. The ECM is composed of 
more than 300 different proteins that can be broadly divided into collagens, proteoglycans, glycoproteins and other ECM associated proteins [1]. These include ECM-sequestered growth factors, cytokines and chemokines. The ECM hence functions as a reservoir that provides cells with signalling cues for growth, survival, proliferation, polarity, migration and differentiation [1-4]. Alterations in the composition of the ECM may therefore impact greatly on cellular behaviour as seen during cancer progression [5].

Cells sense ECM changes through cell surface localised receptors, such as integrins. Integrins are heterodimeric receptors consisting of one $\alpha$ subunit, one $\beta$ subunit [6,7]. In vertebrates, there are $18 \alpha$ - and $8 \beta$-subunits that give rise to 24 known integrins [8,9]. Both subunits consists of an intracellular and an extracellular domain, and a single-pass transmembrane domain [6]. Once activated, the extracellular domain can anchor cells to various types of ECM molecules, where the binding specificity depends on the $\alpha$ - and $\beta$ subunit combination [8]. The intracellular domain physically links to the cells' cytoskeleton and simultaneously activates signalling events [8]. Thus, binding between integrins and ligands can trigger intracellular signalling, where integrins are known to mediate both inside-out and outside-in signalling. The inside-out signalling activates integrins from within the cells, extending the integrin into its active form [7]. Outside-in signalling is induced through integrin-binding to, e.g., ECM proteins, triggering signalling pathways including the FAK/SRC, PI3K/AKT and MAPK/ERK pathways via the cytoplasmic tail of the integrin [6,7]. This gives integrins the power to change both cell morphology, motility and gene expression simply through ECM binding. Integrins are expressed in a cell type- and tissue-specific manner, where expression is rapidly regulated with changes in the cellular environment [8]. Integrins can be categorised into four main groups according to their ligand-binding specificities: laminin-, collagen-, and RGD-binding integrins, in addition to leukocyte-specific integrins [7]. Integrin $\alpha 8 \beta 1$ belongs to the RGD-binding group of integrins which recognises proteins containing the tripeptide Arg (R)-Gly (G)-Asp (D), where the RGD-containing ECM protein nephronectin (NPNT) is believed to be the most prominent. NPNT not only provides a structural foundation for cells through its incorporation into the basement membrane, but also triggers intracellular signalling in a spatiotemporal manner that is particularly important during differentiation and development. Such processes are often exploited by cancer cells and they are therefore important to fully understand to enable therapeutic intervention. To understand the role of NPNT in cancer progression, we will start by reviewing the structure and domainrelated functions of NPNT. Thereafter, we will discuss expression and regulation of the protein, and review studies that explore the roles of NPNT in vivo with special emphasis on cancer-related processes, and in particular metastasis.

\section{Nephronectin (NPNT)}

NPNT was originally identified as an ECM protein by two independent research groups in $2001[10,11]$. Brandenberger et al. reported NPNT to be involved in the embryonic development of the kidney, hence the name nephronectin (nephron: unit within the kidney; nectin: cellular adhesion proteins) [11]. Morimura and colleagues discovered the same protein to be associated with osteoblast differentiation, and named it preosteoblast epidermal growth factor-like repeat protein with meprin, A5 protein and receptor proteintyrosine phosphatase $\mu$ domain (POEM) [10]. For this review, we will use the name nephronectin (NPNT).

\section{NPNT Structure and Domain Related Functions}

NPNT was first reported to be a secreted and glycosylated ECM protein of 70-90 kDa. It was later discovered that NPNT is also located intracellularly [12]. NPNT comprises three functional domains: the five $\mathrm{N}$-terminal epidermal growth factor (EGF)-like repeats, a central linker region with a proline-rich, mucin-like region containing two integrin-binding sequences, and a C-terminal MAM domain (Figure 1) [11,13]. An NPNT homolog also exists, termed epidermal growth factor-like protein 6 (EGFL6, also known as MAEG). How- 
ever, EGFL6 lacks one of the integrin-binding motifs (LFEIFEIER) [14,15]. The combination of these domains gives NPNT diverse functions which are summarised below.

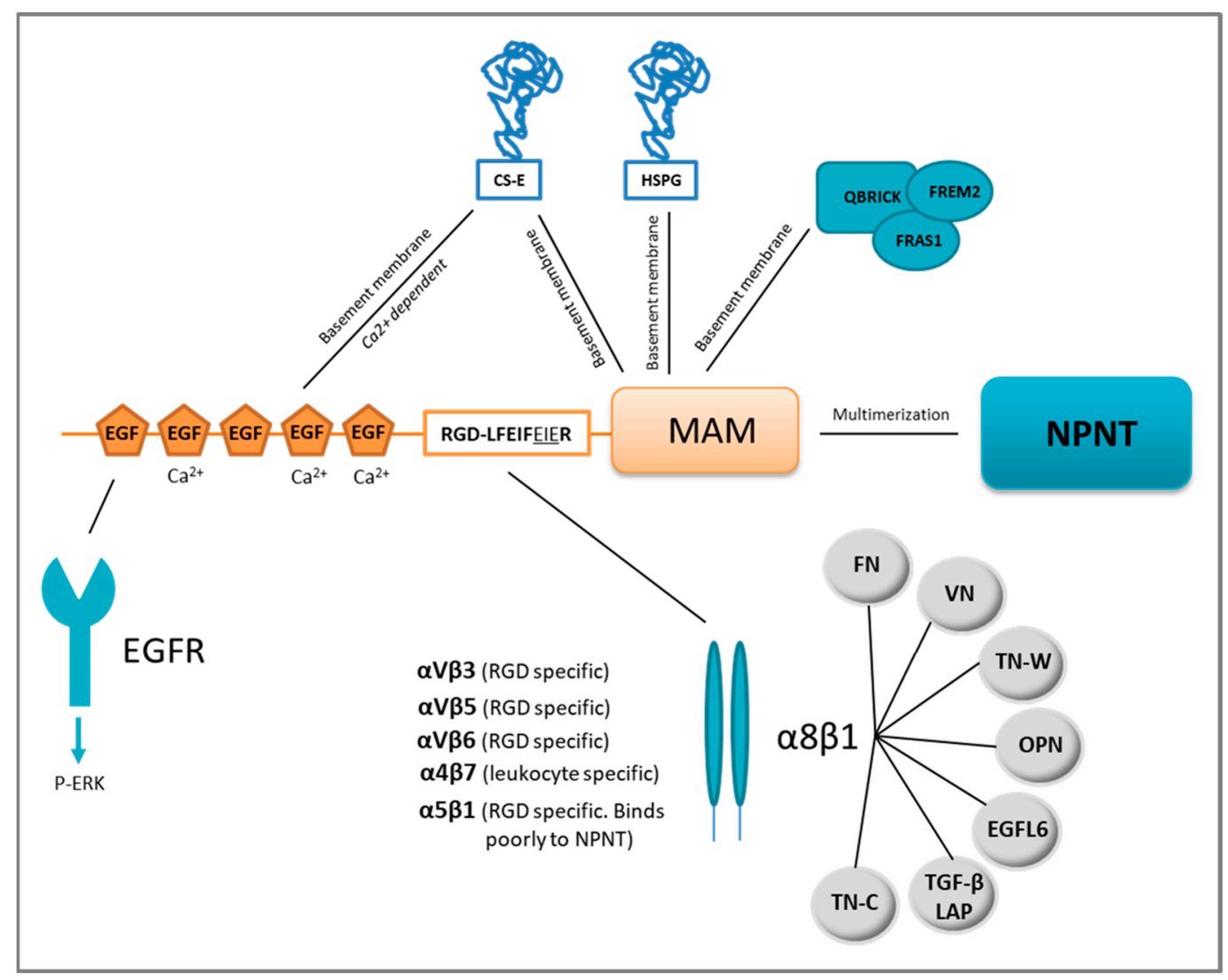

Figure 1. Nephronectin (NPNT) structure, domain-related binding partners and NPNT-integrin redundancy. NPNT consists of three main domains, the N-terminal EGF-like repeats, the linker-region containing two integrin-binding motifs, and the C-terminal MAM domain. The EGF-like repeats may bind the epidermal growth factor receptor (EGFR) and trigger intracellular signalling via ERK phosphorylation (P). Chondroitin sulphate-E (CS-E) can also bind to NPNT via the EGF-like repeats and the MAM domain. The MAM domain is responsible for binding to heparan sulphate proteoglycans (HSPG) in the basement membrane. NPNT may also bind QBRICK, FRAS1 and FREM2 in the basement membrane via its MAM domain. NPNT may multimerise via the MAM domain, and bind several different integrins, most prominently $\alpha 8 \beta 1$, which may furthermore associate with several other binding partners. $\mathrm{FN}=$ fibronectin, $\mathrm{VN}=$ vitronectin, $\mathrm{OPN}=$ osteopontin, $\mathrm{TN}-\mathrm{C}=$ tenascin- $\mathrm{C}, \mathrm{TN}-\mathrm{W}=$ tenascin-W, TGF- $\beta \mathrm{LAP}=$ transforming growth factor- $\beta$ latency-associated protein.

\subsection{EGF-Like Repeats}

NPNT contains five EGF-like repeats [11], which are evolutionarily conserved protein domains found in many extracellular proteins [16] including tenascin-C [17], fibrillin-1 [18], jagged 1 [19] and factor IX [20]. Three of the EGF-like repeats of NPNT are believed to be $\mathrm{Ca}^{2+}$-binding [21], a property that is usually associated with interactions of similar domain types, but may also involve other structural motifs [16]. Some EGF-like repeats can bind and activate the EGF receptor (EGFR), triggering proliferation, migration and differentiation [17]. The EGF-like repeats of NPNT were assumed to bind the EGFR, as they were reported to initiate PI3K-AKT signalling downstream of EGFR in dental epithelial stem cells [22]. The EGF-like repeats of NPNT also induce differentiation of pre-osteoblastic cells into mature osteoblasts through ERK phosphorylation [23,24]. More recently, the EGF-like repeats of NPNT were shown to induce angiogenesis in vitro through ERK and p38 MAPK phosphorylation [25]. The NPNT homolog EGFL6 is also reported to induce angiogenesis [26]. Another reported binding partner of the NPNT EGF-like repeats is the ECM protein chondroitin sulphate-E (CS-E) (Figure 1), a binding partially dependent 
on $\mathrm{Ca}^{2+}$, as it can be reduced by the addition of EDTA. It has been hypothesised that the binding of NPNT to CS-E is needed for deposition of NPNT into basement membranes [27].

\subsection{Linker Region (RGD- and LFEIFEIER Peptide Sequences)}

Mucins are a family of large and highly O-glycosylated proteins, prominent in the glycocalyx of mucosal epithelia where they are located at the epithelial cell surface. Mucins are important for protective barrier functions of the mucosa and expressed in tissues like the intestine, respiratory tract, eye and middle ear epithelium [28]. The linker region of NPNT resembles a mucin, rich in proline, serine and threonine and highly O-glycosylated with a sialic acid cap $[11,13,29]$. One $\mathrm{N}$-glycosylation site is also predicted to be present in this mucin-like region [11]. The N-terminal two-thirds of the linker region harbours most of the glycosylations [13], while the remaining portion contains two integrin-binding motifs: RGD (Arg-Gly-Asp) and LFEIFEIER (Leu-Phe-Glu-Ile-Phe-Glu-Ile-Glu-Arg). Integrins reported to bind NPNT are integrin $\alpha 5 \beta 1, \alpha \mathrm{V} \beta 3, \alpha \mathrm{V} \beta 5, \alpha \mathrm{V} \beta 6, \alpha 4 \beta 7$ and $\alpha 8 \beta 1[11,30]$ as shown in Figure 1. Of these, the NPNT- $\alpha 8 \beta 1$ is best studied and believed to be most prominent, partly due to the overlapping phenotypes of the $\alpha 8 \beta 1$ and NPNT knock-out mice [31,32].

The RGD motif of NPNT is critical, however not efficient to secure the binding of NPNT to integrin $\alpha 8 \beta 1$ [13]. The LFEIFEIER-motif functions as an integrin-binding enhancer motif, which has thus far only been reported involved in enhancing the specific NPNT- $\alpha 8 \beta 1$ binding $[13,30]$. Sato et al. found that the minimal sequence needed to secure enhancer site binding was EIE (LFEIFEIER) [13], while Sanchez-Cortes et al., using a different method ("self-assembled peptides"), found that the two FEI (LFEIFEIER) motifs were the essential sites. Furthermore, Sanchez-Cortez and colleagues also found that both RGD and LFEIFEIER sites interred equally strong binding to the $\alpha 8 \beta 1$ integrin [30].

Using RGD blocking peptides and NPNT with mutated integrin-binding motifs, the RGD motif of NPNT was shown to facilitate cell attachment of cardiomyocytes, endothelial and breast cancer cells $[12,33,34]$. Furthermore, by mutating the integrin-binding motifs, metastasis of breast cancer cells was significantly reduced [12,34]. Through antibody blocking of the RGD and LFEIFEIER sequence, collagen-induced inflammatory arthritis was reduced [35]. The RGD and partially the LFEIFEIER sequence have also been suggested to be involved in recruitment of CD4+ T cells in both acute and chronic liver hepatitis [36].

\subsection{MAM Domain}

MAM domains are found in a variety of proteins, including ECM and several transmembrane proteins. The domain consists of approximately 170 amino acids and contains four cysteine residues that potentially form disulphide bridges [27,37]. MAM domains are assumed to contribute to the proteins' adhesive properties [38], including cell-cell adhesion. When NPNT was expressed in fibroblast-like and pre-osteoblast cells, the protein was not released into the culture medium, but was assumed to be attached to the cell surface. By removing the MAM domain, the protein was released into the medium, indicating that the MAM domain was indeed involved in the cell surface localization of NPNT. When a mutated recombinant NPNT (RGD -> RGE), lacking the EGF domains, was used for coating in cell adhesion studies, leukemic-derived cells stably expressing integrin $\alpha 8 \beta 1$ showed reduced survival and cell spreading. Though the cells did not spread out, they adhered to the coated surface through binding to the remaining MAM domain. This shows that the MAM domain plays a role in the initial phases of cell adhesion [10]. Some MAM-containing proteins may form dimers through their MAM domains [39,40], where the NPNT MAM domain is likely involved in the formation of NPNT multimers [10,13]. The importance of multimeric NPNT is not known, but could be related to its localisation and functions in different basement membranes. Through the MAM domain, NPNT binds to basement membrane located proteins. These include heparan sulphate (HS) proteoglycans (HSPG), like agrin and perlecan, chondroitin sulphate (CS)-E, QBRICK, FRAS1 and FREM2 [27,41]. NPNT also binds the highly sulphated glycosaminoglycan, heparin [27]. The MAM do- 
main was, however, not involved in binding to CS-A, CS-C, CS-D, dermatan sulphate or hyaluronan, see Figure 1 [27]. The importance of the localisation of NPNT in the basement membrane is exemplified in the study of Fraser syndrome. Fraser syndrome is a rare autosomal recessive multiorgan congenital disorder that leads to fused eyelids, fingers and toes as well as renal agenesis, pulmonary complications and diverse morphogenetic defects. When the basement membrane protein QBRICK is dysfunctional, it provokes Fraser syndrome. QBRICK facilitates the assembly of NPNT into the basement membrane (together with FRAS1 and FREM2), where the MAM domain ensures the binding. Without QBRICK or NPNT, integrin $\alpha 8 \beta 1$ binding to the basement membrane could not occur. Although the NPNT homolog EGFL6/MAEG was present, this could not secure the $\alpha 8 \beta 1$ binding. The authors showed that NPNT was a higher-affinity ligand for $\alpha 8 \beta 1$. Integrin $\alpha 8 \beta 1$ binding is important for cell differentiation and organ development and its loss leads to the widespread defects observed [32,41,42].

\section{Expression and Functional Roles of NPNT}

NPNT expression is restricted to specific sites during tissue development and tissue homeostasis, where it plays a pivotal role in cell differentiation $[32,42,43]$. NPNT is expressed in the developing mouse embryo in many different types of tissues. These include the developing renal tubules, parathyroid and thyroid glands, endocrine organs and choroid plexus of the brain, tooth germs, lens of the eyes, the basal lamina of the apical surface of the ear epithelia, Rathke's pouch, basal lamina of the lip and skin epithelium, basal lamina of the lungs, stomach, developing bone, oesophagus and taste buds of the tongue. Expression is somewhat weaker in the muscles of the tongue, developing pancreas and the lobe of the liver $[10,11]$. NPNT knock-out mice $\left(\mathrm{NPNT}^{-/-}\right)$display renal agenesis and hypoplasia [11,32]. This phenotype resembled that of mice with non-functional integrin $\alpha 8 \beta 1$ [31], which triggered Reichardt and colleagues to test whether NPNT was the binding partner of integrin $\alpha 8 \beta 1[11,32]$. Integrin $\alpha 8 \beta 1$ is a member of the RGD-binding group of integrins, where the $\alpha 8$ subunit associates exclusively with the $\beta 1$ subunit $[44,45]$. The $\alpha 8$ subunit is expressed in vascular and visceral smooth muscle, liver stellate cells, and smooth muscle-like contractile cells. In addition, the kidney mesenchyme (mesangial cells) expresses $\alpha 8$, as well as one cell type in the alveolar wall of the lungs, most likely the alveolar myofibroblasts [44-46]. Müller et al. reported expression of the $\alpha 8$ subunit in mesenchymal but not epithelial cells of developing organs such as the gut, lung, gonads and the nephrogenic cord [31]. A crucial role for $\alpha 8 \beta 1$ has been uncovered in early steps of kidney morphogenesis in both mice [31] and humans [47]. Integrin $\alpha 8^{-/-}$knock-out mice display frequent renal agenesis or hypoplasia, but also inner ear hair cell (stereocilia) defects [7,31]. Linton et al. could show that the NPNT- $\alpha 8 \beta 1$ interaction plays an important role in embryonic kidney development, and is required for the invasion of the metanephric mesenchyme by the epithelial cells of the uretic bud during kidney development. The downstream signalling was shown to be elicited through the glial cell line-derived neurotrophic factor (GDNF), a member of the TGF- $\beta$ superfamily [32]. Although NPNT is expressed in many specific tissues during development, only the kidneys show macroscopic abnormalities in $\mathrm{NPNT}^{-/-}$mice. This indicates that there is a functional redundancy of the NPNT-integrin $\alpha 8 \beta 1$ interaction (Figure 1) [32]. In addition to NPNT, $\alpha 8 \beta 1$ can bind [10,11,13] fibronectin (FN) [48], vitronectin (VN) [46], tenascin-C (TN-C) [49], osteopontin (OPN) [50], tenascin-W $(\mathrm{TN}-\mathrm{W})[51]$ and the latency-associated peptide (LAP) of transforming growth factor- $\beta 1$ (TGF- $\beta 1$ ) [52] and EGFL6 [42]. Functional redundancy of the NPNT-integrin $\alpha 8 \beta 1$ interaction has been confirmed studying hair follicles of the epidermis [42]. Fujiwara et al. found that the stem cells in the hair follicle bulge deposited NPNT into the underlying basement membrane. Mesenchymal cells expressing integrin $\alpha 8 \beta 1$ adhered to NPNT and up-regulated smooth muscle markers, triggering arrector pili muscle cell transformation. However, in $\mathrm{NPNT}^{-/-}$mice, the arrector pili muscle cells adhered, not to the bulge, but rather to the follicle above the bulge where the NPNT homolog, EGFL6, was expressed [42]. A similar functional redundancy was observed in the developing heart of zebrafish. NPNT 
is an upstream regulator of Bmp2-Has2 signalling, and inhibition of the signalling cascade caused failure of heart valve formation. However, integrin $\alpha 8 \beta 1$ was not found expressed in the tissue and was therefore most probably not involved in the process [53], indicating the involvement of an alternative receptor.

Whereas the function of NPNT in renal development is well established, much less is known about the function of NPNT expression in the choroid plexus of the brain, lens of the eye, parathyroid and thyroid glands, and the basal lamina of the apical surface of the ear epithelia. Interestingly, $\alpha 8^{-/-}$knock-out mice also display inner ear hair cell (stereocilia) defects [31]. This warrants further investigation. NPNT is also heavily expressed in lung tissue. Increased serum levels of NPNT are linked to silicosis, a type of lung fibrosis [54]. Furthermore, through genome-wide association meta-analysis, NPNT was one of several genes associated with lung function and the susceptibility of developing chronic obstructive pulmonary disease (COPD) $[55,56]$. A recent preprint indicates that a splice variant of NPNT includes an additional serine residue in the splice site, and is associated with COPD. The serine residue is predicted to be located between the signal peptide and the first EGF-like repeat [57]. The structure and function of this newly discovered variant of NPNT is still to be resolved. NPNT is also elevated in diabetic glomerulosclerosis and nephropathy [58,59] and a maker for glomerular regeneration [60].

As previously reviewed by Sun et al., expression of the NPNT gene is regulated by several different signalling pathways [61]. As summarised in Table 1, NPNT is induced and repressed by a diverse spectrum of factors. 
Table 1. Expression and repression of the NPNT gene. Regulation is indicated by colour-coding: up = green, down = red . The downstream signalling pathways/effector(s) are shown and their references. ERK = extracellular signal-regulated kinase, MAPK = mitogen-activated protein kinase, ALK = anaplastic lymphoma kinase, JNK = c-Jun N-terminal kinase, PI3K = phosphoinositide 3-kinase, Klf2 = Kruppel-like factor 2, FGFR = fibroblast growth factor, JAK = Janus kinase, STAT = signal transducer and activator of transcription proteins, TCF $=$ T-cell specific transcription factor, $\mathrm{LEF}=$ lymphoid enhancer binding factor, $\mathrm{Wnt}=$ wingless-related integration site, IGFR = insulin growth factor receptor, Sp1 = specificity protein 1 .

\begin{tabular}{|c|c|c|c|}
\hline Regulatory Effect on NPNT & Initiator(s) & Downstream Effector(s) & References \\
\hline \multirow{7}{*}{ Down-regulation } & Tumour necrosis factor $\alpha(\mathrm{TNF} \alpha)$ & Nuclear factor-kB (NF-kB) & [62] \\
\hline & Transforming growth factor $\beta$ (TGF- $\beta$ ) & $\begin{array}{c}\text { ALK5, Smad2 } \\
\text { ERK1/2, JNK, MAPK }\end{array}$ & {$[23,63,64]$} \\
\hline & Fibroblast growth factor-2 (FGF-2) & $\begin{array}{l}\text { JNK } \\
\text { PI3K }\end{array}$ & [65] \\
\hline & Interleukin- $1 \beta(\mathrm{IL}-1 \beta)$ & $\begin{array}{c}\text { JNK } \\
\text { ERK1/2 }\end{array}$ & {$[66]$} \\
\hline & Oncostatin M (OSM) & $\begin{array}{l}\text { JAK/STAT } \\
\text { MAPK }\end{array}$ & [67] \\
\hline & Inorganic Phosphate & FGFRs (via Pit) & [68] \\
\hline & Mmu-miRNAs 23a, 101a, 296-5p, 328, 425 & GSK3 $\beta$, Cyclin D, ERK & [69] \\
\hline \multirow{6}{*}{ Up-regulation } & $\begin{array}{c}\text { Wnt3a } \\
\text { Wnt }\end{array}$ & $\beta$-catenin, TCF/LEF & {$[42,70,71]$} \\
\hline & Bone morphogenetic protein-2 (BMP-2) & & [72] \\
\hline & Vitamin $\mathrm{D}_{3}$ & Vitamin D receptor (VDR) & {$[73]$} \\
\hline & Fibroblast growth factor 10 (FGF10) & $\begin{array}{l}\text { transcription factor } \mathrm{T} \text { box } 5 \\
(\mathrm{Tbx} 5)\end{array}$ & [43] \\
\hline & Insulin growth factor (IGF) & IGFR-ERK1/2 & {$[74]$} \\
\hline & ? & ERK5-Sp1-Klf2/4 & [75] \\
\hline
\end{tabular}

Most studies on NPNT regulation (Table 1) are done on osteoblasts, where the protein has a central role in differentiation. However, different effects might be expected in cancer cells. This remains to be tested. Exogenously supplied NPNT induces osteoblast differentiation in pre-osteoblast cells, and the process is mediated through the EGF-like repeats [24]. Fang and colleagues showed that TGF- $\beta 1$ inhibits NPNT-induced osteoblast differentiation [23]. TGF- $\beta 1$ stimulates the early steps of osteoblast differentiation, but inhibits the final steps [76]. Cultured pre-osteoblasts stimulated with TGF- $\beta 1$ downregulated NPNT expression and differentiation was inhibited [64,77]. The suppression was transferred through TGF- $\beta 1$-induced phosphorylation of ERK1/2 and JNK in the osteoblasts [64]. It has also been shown that microRNA (miR) plays a part in the regulation of NPNT and osteoblast differentiation [69,78]. Yang and colleagues found five potential miRNAs that can bind to the $3^{\prime}$ UTR of NPNT and by that regulate osteoblast differentiation: these included mmu-miR23a, 101a, 296-5p, 328 and 425. The authors suggested that the regulation was through GSK3 $\beta$, Cyclin D and ERK [69]. Wnt3a is one of the signalling molecules reported to up-regulate NPNT expression in the human pre-osteoblastic cell line MC3T3-E1. The up-regulation was mediated through $\beta$-catenin signalling [70], a finding supported by the coinciding observation that NPNT expression is up-regulated in the $\mathrm{K} 14 \Delta \beta$-cateninER mice where a stabilised $\beta$-catenin is expressed [42].

\section{The Metastasis-Promoting Protein NPNT}

Cancer cells have the ability to exploit mechanisms that are normally used during embryogenesis and differentiation to increase the cancer cells' ability to thrive and spread, of which the most well-known is epithelial-to-mesenchymal transition. As NPNT seems to play a pivotal role in organogenesis and differentiation, it is not surprising that the protein 
can be exploited also during cancer progression. Simple alterations in the ECM composition in cancer may very well impact on cancer cell survival, proliferation, migration, invasion and metastasis.

A role for NPNT has been suggested in several different cancer types, including promoting migration, invasion and poor prognosis in gastric cancer [79], promoting bone metastasis in breast cancer [80], and promoting anti-adhesive and anti-apoptotic behaviour to human adrenocortical carcinoma cells [71]. NPNT also induced hormone production (aldosterone) in a type of adenoma, indicating that NPNT has diverse functional roles also in cancer [71]. Low levels of NPNT in Laron syndrome was correlated to low prevalence of cancer in a large epidemiological study of individuals with this syndrome. Though insulin growth factor 1 is down-regulated in Laron syndrome and induces NPNT expression [74], a cancer-protective role of NPNT still needs verification. Though most studies link NPNT to cancer progression, one study shows that a down-regulation of NPNT in malignant melanoma was linked to cancer progression [81]. Most notably invasion and migration was reduced when NPNT was reintroduced into cancer cells, and cell adhesion was increased [81].

A role for NPNT in promoting breast cancer metastasis was first reported in 2005 by Eckhardt and colleagues [82]. Five breast cancer cell lines, each with a different propensity to metastasise, were injected into the mammary fat pad of syngeneic BALB/c mice. Distant metastasis was scored and the five cell lines were classified as either non-metastatic (67NR), weakly metastatic (168FARN and 66cl4) or highly metastatic cells (4T1.2 and 4T1.13). Analysis of differential gene expression showed that the highly metastatic cells had significantly higher expression of NPNT. When NPNT was knocked down using shRNA, the rate of metastasis was reduced, indicating that NPNT plays a role in promoting metastasis [82]. More recently, using formalin-fixed and paraffin-embedded tissues from a well-characterised cohort of 842 Norwegian women diagnosed with invasive breast cancer (1961-2008) [83], we showed that NPNT protein was expressed in more than 70\% of all primary breast cancers. A granular intracellular staining pattern was correlated to poor prognosis. No expression of NPNT was found in normal breast tissue [12,34]. A similar granular staining pattern was found in mouse breast cancer tissues, and mouse breast cancer cells secreted small extracellular vesicles containing NPNT. Another intriguing finding was the selected packaging of a truncated form of NPNT ( 20 kDa) into small extracellular vesicles secreted from mouse breast cancer cells. The truncated NPNT most likely corresponded to the MAM domain [29]. Additionally, Morimura et al. reported a similar truncated ( 25-30 kDa) and secreted form of NPNT [10]. The truncated NPNT was selectively concentrated into the small extracellular vesicles [29], indicating that the truncated version could have a specific function. Certain small extracellular vesicles can create pre-metastatic niches, enabling circulating cancer cells to seed and colonise in initially inhabitable soils [84]. Whether these small extracellular vesicles containing NPNT create such a pre-metastatic niche needs to be tested. We did, however, find that mouse breast cancer cells overexpressing wild type NPNT metastasised more readily to the lungs compared to control cells. However, when the integrin-binding motifs were mutated (RGD -> RGE and EIE -> AIA), the ability to colonise the lungs was reduced. These results showed that the integrin-binding motifs play a direct role in promoting metastasis [12]. The cancer cells were tail vein injected, bypassing the first steps of metastasis (invasion and intravasation), hence we could only conclude on the role of NPNT in the final steps of metastasis (survival in the circulation, extravasation or colonization). More recently we reported that the integrin-binding motifs of NPNT play a role specifically in extravasation during breast cancer brain metastasis. NPNT increased the cells' ability to bind to-and migrate through-brain endothelial cells. Though more work is needed to validate these findings, this indicates that NPNT may play a part in transmigration of the endothelium [34]. Hypothetically, NPNT could function as a bridging molecule between disseminating cancer cells and the endothelial wall. In support of this hypothesis, once secreted, NPNT may bind to its own cell surface either via the MAM domain or the 
integrin-binding motifs $[10,34]$. NPNT harbours five EGF-like repeats that may be able to bind EGFR [22]. Additionally, both the EGF-like domains and the MAM domain are known to bind basement membrane proteins such as HSPG, CS, QBRICK, FRAS1 and FREM2, where CS-E is known to be expressed in the brain, kidney, cartilage and hair follicles [27]. Taken together, NPNT may promote metastasis through several mechanisms, including increased survival, angiogenesis, migration, extravasation and colonization.

\section{Future Perspectives}

The interactions between the extracellular matrix and receptors such as integrins play important roles in several different types of diseases such as thrombosis, inflammation, fibrosis and cancer. These interactions pose as desired drug targets especially due to their accessibility [85]. However, many integrin-targeting drugs have failed in clinical trials. Cilengitide, targeting the RGD motif, failed due to lack of efficiency [86,87]. In this regard, the NPNT-Integrin $\alpha 8 \beta 1$ interaction may present an alternative target for therapy. NPNT induced viability of cancer cells by activating the p38 MAPK pathway through its integrinbinding motifs. Interestingly, it was mainly the LFEIFEIER-enhancer motif that caused the activation of p38 MAPK and increased cell viability in breast cancer cells [88]. Our results indicated that NPNT plays a role during metastasis and in particular extravasation [34], and by mutating the RGD site, some of the metastatic burden was reduced. However, when both integrin motifs were mutated, the metastasis was reduced to baseline levels [12]. This indicates a particular important role of the LFEIFEIER-motif in the metastatic process. Another issue when targeting integrins is redundancy. In the case of the LFEIFEIER-motif it is, to the best of our knowledge, only reported to enhance the NPNT-Integrin $\alpha 8 \beta 1$ binding. Although redundant interactions of integrin $\alpha 8 \beta 1$ exist, they may not always be "functional". As shown by Kiyozumi et al., the NPNT homolog MAEG/EGFL6, which lacks the LFEIFEIER-motif, was unable to secure the $\alpha 8 \beta 1$ binding even though it contains the common RGD-motif [41]. We therefore propose that the LFEIFEIER-motif could be an attractive therapeutic target in cancers with high levels of NPNT. Due to the additional importance of the RGD motif, a combinatorial treatment along with inhibitors such as cilengitide might be an attractive approach. To the best of our knowledge, such inhibitors do not exist and warrants further investigation.

Thus far, NPNT is reported to play a role in a limited number of cancer types, but given its many domain-related functions and specific expression pattern, we believe many more important roles are still to be uncovered.

Author Contributions: Conceptualization, S.N.M. and J.T.; funding acquisition, S.N.M., E.H.-O., T.S.S. and G.S.; writing - original draft preparation, S.N.M. and J.T.; writing-review and editing, S.N.M., J.T., E.H.-O., T.S.S. and G.S.; project administration, S.N.M., T.S.S., E.H.-O. and G.S. All authors have read and agreed to the published version of the manuscript.

Funding: The publication charges for this article have been funded by a grant from the publication fund at UiT-The Arctic University of Norway. This work was supported by grants from the North Norwegian Regional Health Authorities (SPF1232-15), The Erna and Olav Aakre Foundation for Cancer Research, The Blix Family Fund for Medical Research, The Terje and Valeria Stalder Jacobsen Research Fund, UiT- The Arctic University of Norway, The Liaison Committee between the Central Norway Regional Health Authority and the Norwegian University of Science and Technology (NTNU), the Norwegian Cancer Society (2290738-2011), The National Research Development and Innovation Office (K116158, FK-124114, GINOP-2.3.2-15-2016-00020, GINOP-2.3.2-15-2016-00030 and GINOP-2.3.2-15-2016-00034).

Acknowledgments: The authors thank Peter McCourt for linguistic revision of the manuscript.

Conflicts of Interest: The authors declare no conflict of interest. The funders had no role in the design of the study; in the collection, analyses, or interpretation of data; in the writing of the manuscript, or in the decision to publish the results. 


\section{References}

1. Bonnans, C.; Chou, J.; Werb, Z. Remodelling the extracellular matrix in development and disease. Nat. Rev. Mol. Cell Biol. 2014, 15, 786-801. [CrossRef]

2. Hynes, R.O. The extracellular matrix: Not just pretty fibrils. Science 2009, 326, 1216-1219. [CrossRef] [PubMed]

3. Gilkes, D.M.; Semenza, G.L.; Wirtz, D. Hypoxia and the extracellular matrix: Drivers of tumour metastasis. Nat. Rev. Cancer 2014, 14, 430-439. [CrossRef]

4. Malandrino, A.; Mak, M.; Kamm, R.D.; Moeendarbary, E. Complex mechanics of the heterogeneous extracellular matrix in cancer. Extrem. Mech. Lett. 2018, 21, 25-34. [CrossRef]

5. Walker, C.; Mojares, E.; Del Rio Hernandez, A. Role of extracellular matrix in development and cancer progression. Int. J. Mol. Sci. 2018, 19. [CrossRef]

6. Longmate, W.; DiPersio, C.M. Beyond adhesion: Emerging roles for integrins in control of the tumor microenvironment. F1000Res 2017, 6, 1612. [CrossRef]

7. Hynes, R.O. Integrins: Bidirectional, allosteric signaling machines. Cell 2002, 110, 673-687. [CrossRef]

8. Barczyk, M.; Carracedo, S.; Gullberg, D. Integrins. Cell Tissue Res. 2010, 339, 269-280. [CrossRef]

9. Giancotti, F.G.; Ruoslahti, E. Integrin signaling. Science 1999, 285, 1028-1032. [CrossRef]

10. Morimura, N.; Tezuka, Y.; Watanabe, N.; Yasuda, M.; Miyatani, S.; Hozumi, N.; Tezuka Ki, K. Molecular cloning of POEM: A novel adhesion molecule that interacts with alpha8beta1 integrin. J. Biol. Chem. 2001, 276, 42172-42181. [CrossRef] [PubMed]

11. Brandenberger, R.; Schmidt, A.; Linton, J.; Wang, D.; Backus, C.; Denda, S.; Muller, U.; Reichardt, L.F. Identification and characterization of a novel extracellular matrix protein nephronectin that is associated with integrin alpha8beta1 in the embryonic kidney. J. Cell. Biol. 2001, 154, 447-458. [CrossRef]

12. Steigedal, T.S.; Toraskar, J.; Redvers, R.P.; Valla, M.; Magnussen, S.N.; Bofin, A.M.; Opdahl, S.; Lundgren, S.; Eckhardt, B.L.; Lamar, J.M.; et al. Nephronectin is correlated with poor prognosis in breast cancer and promotes metastasis via its integrin-binding motifs. Neoplasia 2018, 20, 387-400. [CrossRef] [PubMed]

13. Sato, Y.; Uemura, T.; Morimitsu, K.; Sato-Nishiuchi, R.; Manabe, R.; Takagi, J.; Yamada, M.; Sekiguchi, K. Molecular basis of the recognition of nephronectin by integrin alpha8beta1. J. Biol. Chem. 2009, 284, 14524-14536. [CrossRef]

14. Yeung, G.; Mulero, J.J.; Berntsen, R.P.; Loeb, D.B.; Drmanac, R.; Ford, J.E. Cloning of a novel epidermal growth factor repeat containing gene EGFL6: Expressed in tumor and fetal tissues. Genomics 1999, 62, 304-307. [CrossRef] [PubMed]

15. Buchner, G.; Orfanelli, U.; Quaderi, N.; Bassi, M.T.; Andolfi, G.; Ballabio, A.; Franco, B. Identification of a new EGF-repeatcontaining gene from human Xp22: A candidate for developmental disorders. Genomics 2000, 65, 16-23. [CrossRef] [PubMed]

16. Rao, Z.; Handford, P.; Mayhew, M.; Knott, V.; Brownlee, G.G.; Stuart, D. The structure of a Ca(2+)-binding epidermal growth factor-like domain: Its role in protein-protein interactions. Cell 1995, 82, 131-141. [CrossRef]

17. Swindle, C.S.; Tran, K.T.; Johnson, T.D.; Banerjee, P.; Mayes, A.M.; Griffith, L.; Wells, A. Epidermal growth factor (EGF)-like repeats of human tenascin-C as ligands for EGF receptor. J. Cell. Biol. 2001, 154, 459-468. [CrossRef]

18. Handford, P.A. Fibrillin-1, a calcium binding protein of extracellular matrix. Biochim. Biophys. Acta 2000, 1498, 84-90. [CrossRef]

19. Morrissette, J.J.D.; Colliton, R.P.; Spinner, N.B. Defective intracellular transport and processing of JAG1 missense mutations in Alagille syndrome. Hum. Mol. Genet. 2001, 10, 405-413. [CrossRef]

20. Handford, P.A.; Baron, M.; Mayhew, M.; Willis, A.; Beesley, T.; Brownlee, G.G.; Campbell, I.D. The first EGF-like domain from human factor IX contains a high-affinity calcium binding site. EMBO 1990, 9, 475-480. [CrossRef]

21. Huang, J.T.; Lee, V. Identification and characterization of a novel human nephronectin gene in silico. Int. J. Mol. Med. 2005, 15, 719-724. [CrossRef]

22. Arai, C.; Yoshizaki, K.; Miyazaki, K.; Saito, K.; Yamada, A.; Han, X.; Funada, K.; Fukumoto, E.; Haruyama, N.; Iwamoto, T.; et al. Nephronectin plays critical roles in Sox2 expression and proliferation in dental epithelial stem cells via EGF-like repeat domains. Sci. Rep. 2017, 7, 45181. [CrossRef]

23. Fang, L.; Kahai, S.; Yang, W.; He, C.; Seth, A.; Peng, C.; Yang, B.B. Transforming growth factor-beta inhibits nephronectin-induced osteoblast differentiation. FEBS Lett. 2010, 584, 2877-2882. [CrossRef] [PubMed]

24. Kahai, S.; Lee, S.C.; Seth, A.; Yang, B.B. Nephronectin promotes osteoblast differentiation via the epidermal growth factor-like repeats. FEBS Lett. 2010, 584, 233-238. [CrossRef] [PubMed]

25. Kuek, V.; Yang, Z.; Chim, S.M.; Zhu, S.; Xu, H.; Chow, S.T.; Tickner, J.; Rosen, V.; Erber, W.; Li, X.; et al. NPNT is expressed by osteoblasts and mediates angiogenesis via the activation of extracellular signal-regulated kinase. Sci. Rep. 2016, 6, 36210. [CrossRef]

26. Chim, S.M.; Qin, A.; Tickner, J.; Pavlos, N.; Davey, T.; Wang, H.; Guo, Y.; Zheng, M.H.; Xu, J. EGFL6 promotes endothelial cell migration and angiogenesis through the activation of extracellular signal-regulated kinase. J. Biol. Chem. 2011, 286, 22035-22046. [CrossRef] [PubMed]

27. Sato, Y.; Shimono, C.; Li, S.; Nakano, I.; Norioka, N.; Sugiura, N.; Kimata, K.; Yamada, M.; Sekiguchi, K. Nephronectin binds to heparan sulfate proteoglycans via its MAM domain. J. Int. Soc. Matrix Biol. 2013, 32, 188-195. [CrossRef] [PubMed]

28. Linden, S.K.; Sutton, P.; Karlsson, N.G.; Korolik, V.; McGuckin, M.A. Mucins in the mucosal barrier to infection. Mucosal Immunol. 2008, 1, 183-197. [CrossRef]

29. Toraskar, J.; Magnussen, S.N.; Hagen, L.; Sharma, A.; Hoang, L.; Bjorkoy, G.; Svineng, G.; Steigedal, T.S. A novel truncated form of nephronectin is present in small extracellular vesicles isolated from 66cl4 cells. J. Proteome Res. 2019. [CrossRef] [PubMed] 
30. Sanchez-Cortes, J.; Mrksich, M. Using self-assembled monolayers to understand alpha8beta1-mediated cell adhesion to RGD and FEI motifs in nephronectin. ACS Chem. Biol. 2011, 6, 1078-1086. [CrossRef]

31. Muller, U.; Wang, D.; Denda, S.; Meneses, J.J.; Pedersen, R.A.; Reichardt, L.F. Integrin alpha8beta1 is critically important for epithelial-mesenchymal interactions during kidney morphogenesis. Cell 1997, 88, 603-613. [CrossRef]

32. Linton, J.M.; Martin, G.R.; Reichardt, L.F. The ECM protein nephronectin promotes kidney development via integrin alpha8beta1mediated stimulation of Gdnf expression. Development 2007, 134, 2501-2509. [CrossRef] [PubMed]

33. Patra, C.; Ricciardi, F.; Engel, F.B. The functional properties of nephronectin: An adhesion molecule for cardiac tissue engineering. Biomaterials 2012, 33, 4327-4335. [CrossRef] [PubMed]

34. Magnussen, S.N.; Toraskar, J.; Wilhelm, I.; Hasko, J.; Figenschau, S.L.; Molnar, J.; Seppola, M.; Steigen, S.E.; Steigedal, T.S.; Hadler-Olsen, E.; et al. Nephronectin promotes breast cancer brain metastatic colonization via its integrin-binding domains. Sci. Rep. 2020, 10, 12237. [CrossRef] [PubMed]

35. Kon, S.; Honda, M.; Ishikawa, K.; Maeda, M.; Segawa, T. Antibodies against nephronectin ameliorate anti-type II collagen-induced arthritis in mice. FEBS Open. Biol. 2020, 10, 107-117. [CrossRef]

36. Inagaki, F.F.; Tanaka, M.; Inagaki, N.F.; Yagai, T.; Sato, Y.; Sekiguchi, K.; Oyaizu, N.; Kokudo, N.; Miyajima, A. Nephronectin is upregulated in acute and chronic hepatitis and aggravates liver injury by recruiting CD4 positive cells. Biochem. Biophys. Res. Commun. 2013, 430, 751-756. [CrossRef]

37. Osada, A.; Kiyozumi, D.; Tsutsui, K.; Ono, Y.; Weber, C.N.; Sugimoto, N.; Imai, T.; Okada, A.; Sekiguchi, K. Expression of MAEG, a novel basement membrane protein, in mouse hair follicle morphogenesis. Exp. Cell Res. 2005, 303, 148-159. [CrossRef] [PubMed]

38. Beckmann, G.; Bork, P. An adhesive domain detected in functionally diverse receptors. Trends Biochem. Sci. 1993, 18, 40-41. [CrossRef]

39. Cismasiu, V.B.; Denes, S.A.; Reilander, H.; Michel, H.; Szedlacsek, S.E. The MAM (meprin/A5-protein/PTPmu) domain is a homophilic binding site promoting the lateral dimerization of receptor-like protein-tyrosine phosphatase mu. J. Biol. Chem. 2004, 279, 26922-26931. [CrossRef]

40. Yelland, T.; Djordjevic, S. Crystal structure of the neuropilin-1 MAM domain: Completing the neuropilin-1 ectodomain picture. Structure 2016, 24, 2008-2015. [CrossRef]

41. Kiyozumi, D.; Takeichi, M.; Nakano, I.; Sato, Y.; Fukuda, T.; Sekiguchi, K. Basement membrane assembly of the integrin alpha8beta1 ligand nephronectin requires Fraser syndrome-associated proteins. J. Cell. Biol. 2012, 197, 677-689. [CrossRef]

42. Fujiwara, H.; Ferreira, M.; Donati, G.; Marciano, D.K.; Linton, J.M.; Sato, Y.; Hartner, A.; Sekiguchi, K.; Reichardt, L.F.; Watt, F.M. The basement membrane of hair follicle stem cells is a muscle cell niche. Cell 2011, 144, 577-589. [CrossRef]

43. Abu-Daya, A.; Nishimoto, S.; Fairclough, L.; Mohun, T.J.; Logan, M.P.; Zimmerman, L.B. The secreted integrin ligand nephronectin is necessary for forelimb formation in Xenopus tropicalis. Dev. Biol. 2011, 349, 204-212. [CrossRef]

44. Schnapp, L.M.; Breuss, J.M.; Ramos, D.M.; Sheppard, D.; Pytela, R. Sequence and tissue distribution of the human integrin alpha 8 subunit: A beta 1-associated alpha subunit expressed in smooth muscle cells. J. Cell Sci. 1995, 108, 537-544. [PubMed]

45. Zargham, R. Tensegrin in context: Dual role of alpha8 integrin in the migration of different cell types. Cell Adhes. Migr. 2010, 4 , 485-490. [CrossRef] [PubMed]

46. Schnapp, L.M.; Hatch, N.; Ramos, D.M.; Klimanskaya, I.V.; Sheppard, D.; Pytela, R. The human integrin alpha 8 beta 1 functions as a receptor for tenascin, fibronectin, and vitronectin. J. Biol. Chem. 1995, 270, 23196-23202. [CrossRef] [PubMed]

47. Humbert, C.; Silbermann, F.; Morar, B.; Parisot, M.; Zarhrate, M.; Masson, C.; Tores, F.; Blanchet, P.; Perez, M.J.; Petrov, Y.; et al. Integrin alpha 8 recessive mutations are responsible for bilateral renal agenesis in humans. Am. J. Hum. Genet. 2014, 94, 288-294. [CrossRef]

48. Muller, U.; Bossy, B.; Venstrom, K.; Reichardt, L.F. Integrin alpha 8 beta 1 promotes attachment, cell spreading, and neurite outgrowth on fibronectin. Mol. Biol. Cell 1995, 6, 433-448. [CrossRef]

49. Varnum-Finney, B.; Venstrom, K.; Muller, U.; Kypta, R.; Backus, C.; Chiquet, M.; Reichardt, L.F. The integrin receptor alpha 8 beta 1 mediates interactions of embryonic chick motor and sensory neurons with tenascin-C. Neuron 1995, 14, 1213-1222. [CrossRef]

50. Denda, S.; Reichardt, L.F.; Muller, U. Identification of osteopontin as a novel ligand for the integrin alpha8 beta1 and potential roles for this integrin-ligand interaction in kidney morphogenesis. Mol. Biol. Cell 1998, 9, 1425-1435. [CrossRef]

51. Scherberich, A.; Tucker, R.P.; Samandari, E.; Brown-Luedi, M.; Martin, D.; Chiquet-Ehrismann, R. Murine tenascin-W: A novel mammalian tenascin expressed in kidney and at sites of bone and smooth muscle development. J. Cell Sci. 2004, 117, 571-581. [CrossRef]

52. Lu, M.; Munger, J.S.; Steadele, M.; Busald, C.; Tellier, M.; Schnapp, L.M. Integrin alpha8beta1 mediates adhesion to LAP-TGFbeta1. J. Cell Sci. 2002, 115, 4641-4648. [CrossRef]

53. Patra, C.; Diehl, F.; Ferrazzi, F.; van Amerongen, M.J.; Novoyatleva, T.; Schaefer, L.; Muhlfeld, C.; Jungblut, B.; Engel, F.B. Nephronectin regulates atrioventricular canal differentiation via Bmp4-Has2 signaling in zebrafish. Development 2011, 138, 4499-4509. [CrossRef]

54. Lee, S.; Honda, M.; Yamamoto, S.; Kumagai-Takei, N.; Yoshitome, K.; Nishimura, Y.; Sada, N.; Kon, S.; Otsuki, T. Role of nephronectin in pathophysiology of silicosis. Int. J. Mol. Sci. 2019, 20. [CrossRef]

55. Castaldi, P.J.; Cho, M.H.; Litonjua, A.A.; Bakke, P.; Gulsvik, A.; Lomas, D.A.; Anderson, W.; Beaty, T.H.; Hokanson, J.E.; Crapo, J.D.; et al. The association of genome-wide significant spirometric loci with chronic obstructive pulmonary disease susceptibility. Am.J. Respir. Cell Mol. Biol. 2011, 45, 1147-1153. [CrossRef] 
56. Probert, K.; Miller, S.; Kheirallah, A.K.; Hall, I.P. Developmental genetics of the COPD lung. COPD Res. Pract. 2015, 1, 10. [CrossRef]

57. Saferali, A.; Xu, Z.; Sheynkman, G.M.; Hersh, C.P.; Cho, M.H.; Silverman, E.K.; Laederach, A.; Vollmers, C.; Castaldi, P.J. Characterization of a COPD-associated NPNT functional splicing genetic variant in human lung tissue via long-read sequencing. Med. Rxiv. 2020. [CrossRef]

58. Nakatani, S.; Wei, M.; Ishimura, E.; Kakehashi, A.; Mori, K.; Nishizawa, Y.; Inaba, M.; Wanibuchi, H. Proteome analysis of laser microdissected glomeruli from formalin-fixed paraffin-embedded kidneys of autopsies of diabetic patients: Nephronectin is associated with the development of diabetic glomerulosclerosis. Nephrol. Dial. Transplant. 2012, 27, 1889-1897. [CrossRef] [PubMed]

59. Nakatani, S.; Ishimura, E.; Mori, K.; Fukumoto, S.; Yamano, S.; Wei, M.; Emoto, M.; Wanibuchi, H.; Inaba, M. Nephronectin expression in glomeruli of renal biopsy specimens from various kidney diseases: Nephronectin is expressed in the mesangial matrix expansion of diabetic nephropathy. Nephrol. Clin. Pract. 2012, 122, 114-121. [CrossRef]

60. Watany, M.M.; El-Horany, H.E. Nephronectin (NPNT) and the prediction of nephrotic syndrome response to steroid treatment. Eur. J. Hum. Genet. 2018, 26, 1354-1360. [CrossRef]

61. Sun, Y.; Kuek, V.; Qiu, H.; Tickner, J.; Chen, L.; Wang, H.; He, W.; Xu, J. The emerging role of NPNT in tissue injury repair and bone homeostasis. J. Cell. Physiol. 2018, 233, 1887-1894. [CrossRef]

62. Tsukasaki, M.; Yamada, A.; Suzuki, D.; Aizawa, R.; Miyazono, A.; Miyamoto, Y.; Suzawa, T.; Takami, M.; Yoshimura, K.; Morimura, N.; et al. Expression of POEM, a positive regulator of osteoblast differentiation, is suppressed by TNF-alpha. Biochem. Biophys. Res. Commun. 2011, 410, 766-770. [CrossRef] [PubMed]

63. Tsukasaki, M.; Yamada, A.; Yoshimura, K.; Miyazono, A.; Yamamoto, M.; Takami, M.; Miyamoto, Y.; Morimura, N.; Kamijo, R. Nephronectin expression is regulated by SMAD signaling in osteoblast-like MC3T3-E1 cells. Biochem. Biophys. Res. Commun. 2012, 425, 390-392. [CrossRef] [PubMed]

64. Miyazono, A.; Yamada, A.; Morimura, N.; Takami, M.; Suzuki, D.; Kobayashi, M.; Tezuka, K.; Yamamoto, M.; Kamijo, R. TGF-beta suppresses POEM expression through ERK1/2 and JNK in osteoblasts. FEBS Lett. 2007, 581, 5321-5326. [CrossRef]

65. Kato, T.; Yamada, A.; Ikehata, M.; Yoshida, Y.; Sasa, K.; Morimura, N.; Sakashita, A.; Iijima, T.; Chikazu, D.; Ogata, H.; et al. FGF-2 suppresses expression of nephronectin via JNK and PI3K pathways. FEBS Open. Biol. 2018, 8, 836-842. [CrossRef]

66. Iezumi, Y.; Yamada, A.; Minami, E.; Ikehata, M.; Yoshida, Y.; Kato, T.; Morimura, N.; Ogata, H.; Sakashita, A.; Iijima, T.; et al. IL-1beta suppresses nephronectin expression in osteoblasts via ERK1/2 and JNK. Biochem. Biophys. Res. Commun. 2017, 493, 773-775. [CrossRef]

67. Kurosawa, T.; Yamada, A.; Takami, M.; Suzuki, D.; Saito, Y.; Hiranuma, K.; Enomoto, T.; Morimura, N.; Yamamoto, M.; Iijima, T.; et al. Expression of nephronectin is inhibited by oncostatin M via both JAK/STAT and MAPK pathways. FEBS Open. Biol. 2015, 5, 303-307. [CrossRef]

68. Kato, T.; Yamada, A.; Sasa, K.; Yoshimura, K.; Morimura, N.; Ogata, H.; Sakashita, A.; Kamijo, R. Nephronectin expression is inhibited by inorganic phosphate in osteoblasts. Calcif. Tissue Int. 2019, 104, 201-206. [CrossRef]

69. Lee, S.C.; Fang, L.; Wang, C.H.; Kahai, S.; Deng, Z.; Yang, B.B. A non-coding transcript of nephronectin promotes osteoblast differentiation by modulating microRNA functions. FEBS Lett. 2011, 585, 2610-2616. [CrossRef]

70. Ikehata, M.; Yamada, A.; Morimura, N.; Itose, M.; Suzawa, T.; Shirota, T.; Chikazu, D.; Kamijo, R. Wnt/beta-catenin signaling activates nephronectin expression in osteoblasts. Biochem. Biophys. Res. Commun. 2017, 484, 231-234. [CrossRef] [PubMed]

71. Teo, A.E.; Garg, S.; Johnson, T.I.; Zhao, W.; Zhou, J.; Gomez-Sanchez, C.E.; Gurnell, M.; Brown, M.J. Physiological and pathological roles in human adrenal of the glomeruli-defining matrix protein NPNT (Nephronectin). Hypertension 2017, 69, 1207-1216. [CrossRef] [PubMed]

72. Kurosawa, T.; Yamada, A.; Suzuki, D.; Morimura, N.; Sasagane, Y.; Itabe, H.; Kamijo, R. Nephronectin expression is up-regulated by BMP-2. Biol. Pharm. Bull. 2016, 39, 1211-1215. [CrossRef] [PubMed]

73. Hiranuma, K.; Yamada, A.; Kurosawa, T.; Aizawa, R.; Suzuki, D.; Saito, Y.; Nagahama, R.; Ikehata, M.; Tsukasaki, M.; Morimura, N.; et al. Expression of nephronectin is enhanced by 1alpha,25-dihydroxyvitamin D3. FEBS Open. Biol. 2016, 6, 914-918. [CrossRef]

74. Sarfstein, R.; Lapkina-Gendler, L.; Nagaraj, K.; Laron, Z.; Werner, H. Identification of nephronectin as a new target for IGF1 action. Eur. J. Cancer 2020, 141, 115-127. [CrossRef]

75. Sunadome, K.; Yamamoto, T.; Ebisuya, M.; Kondoh, K.; Sehara-Fujisawa, A.; Nishida, E. ERK5 regulates muscle cell fusion through Klf transcription factors. Dev. Cell 2011, 20, 192-205. [CrossRef] [PubMed]

76. Bonewald, L.F.; Dallas, S.L. Role of active and latent transforming growth factor beta in bone formation. J. Cell. Biochem. 1994, 55, 350-357. [CrossRef]

77. Kahai, S.; Vary, C.P.; Gao, Y.; Seth, A. Collagen, type V, alpha1 (COL5A1) is regulated by TGF-beta in osteoblasts. J. Int. Soc. Matrix Biol. 2004, 23, 445-455. [CrossRef]

78. Kahai, S.; Lee, S.C.; Lee, D.Y.; Yang, J.; Li, M.; Wang, C.H.; Jiang, Z.; Zhang, Y.; Peng, C.; Yang, B.B. MicroRNA miR-378 regulates nephronectin expression modulating osteoblast differentiation by targeting GalNT-7. PLoS ONE 2009, 4, e7535. [CrossRef]

79. Mei, D.; Zhao, B.; Zhang, J.; Xu, H.; Huang, B. Nephronectin is a prognostic biomarker and promotes gastric cancer cell proliferation, migration and invasion. Histol. Histopathol. 2020, 18260. [CrossRef] 
80. Wang, D.; Zhao, C.; Gao, L.; Wang, Y.; Gao, X.; Tang, L.; Zhang, K.; Li, Z.; Han, J.; Xiao, J. NPNT promotes early-stage bone metastases in breast cancer by regulation of the osteogenic niche. J. Bone Oncol. 2018, 13, 91-96. [CrossRef]

81. Kuphal, S.; Wallner, S.; Bosserhoff, A.K. Loss of nephronectin promotes tumor progression in malignant melanoma. Cancer Sci. 2008, 99, 229-233. [CrossRef] [PubMed]

82. Eckhardt, B.L.; Parker, B.S.; van Laar, R.K.; Restall, C.M.; Natoli, A.L.; Tavaria, M.D.; Stanley, K.L.; Sloan, E.K.; Moseley, J.M.; Anderson, R.L. Genomic analysis of a spontaneous model of breast cancer metastasis to bone reveals a role for the extracellular matrix. Mol. Cancer Res. MCR 2005, 3, 1-13.

83. Engstrom, M.J.; Opdahl, S.; Hagen, A.I.; Romundstad, P.R.; Akslen, L.A.; Haugen, O.A.; Vatten, L.J.; Bofin, A.M. Molecular subtypes, histopathological grade and survival in a historic cohort of breast cancer patients. Breast Cancer Res. Treat. 2013, 140, 463-473. [CrossRef]

84. Costa-Silva, B.; Aiello, N.M.; Ocean, A.J.; Singh, S.; Zhang, H.; Thakur, B.K.; Becker, A.; Hoshino, A.; Mark, M.T.; Molina, H.; et al. Pancreatic cancer exosomes initiate pre-metastatic niche formation in the liver. Nat. Cell Biol. 2015, 17, 816-826. [CrossRef]

85. Goodman, S.L.; Picard, M. Integrins as therapeutic targets. Trends Pharmacol. Sci. 2012, 33, 405-412. [CrossRef]

86. Stupp, R.; Hegi, M.E.; Gorlia, T.; Erridge, S.C.; Perry, J.; Hong, Y.K.; Aldape, K.D.; Lhermitte, B.; Pietsch, T.; Grujicic, D.; et al. Cilengitide combined with standard treatment for patients with newly diagnosed glioblastoma with methylated MGMT promoter (CENTRIC EORTC 26071-22072 study): A multicentre, randomised, open-label, phase 3 trial. Lancet Oncol. 2014, 15, 1100-1108. [CrossRef]

87. Nabors, L.B.; Fink, K.L.; Mikkelsen, T.; Grujicic, D.; Tarnawski, R.; Nam, D.H.; Mazurkiewicz, M.; Salacz, M.; Ashby, L.; Zagonel, V.; et al. Two cilengitide regimens in combination with standard treatment for patients with newly diagnosed glioblastoma and unmethylated MGMT gene promoter: Results of the open-label, controlled, randomized phase II CORE study. Neuro-Oncol. 2015, 17, 708-717. [CrossRef] [PubMed]

88. Toraskar, J.; Magnussen, S.N.; Chawla, K.; Svineng, G.; Steigedal, T.S. Nephronectin mediates p38 MAPK-induced cell viability via its integrin-binding enhancer motif. FEBS Open. Biol. 2018, 8, 1992-2001. [CrossRef] [PubMed] 